\title{
Introduction. Founding Fathers, Foundering
} Fathers

Romain Graziani

\section{OpenEdition}

1 Journals

Édition électronique

URL : http://journals.openedition.org/extremeorient/205

DOI : 10.4000/extremeorient.205

ISSN : 2108-7105

Éditeur

Presses universitaires de Vincennes

Édition imprimée

Date de publication : 1 janvier 2012

Pagination : 5-30

ISSN : 0754-5010

\section{Référence électronique}

Romain Graziani, «Introduction. Founding Fathers, Foundering Fathers », Extrême-Orient ExtrêmeOccident [En ligne], Hors-série | 2012, mis en ligne le 25 septembre 2012, consulté le 24 septembre 2020. URL : http://journals.openedition.org/extremeorient/205 ; DOI : https://doi.org/10.4000/ extremeorient.205 


\title{
Introduction. Founding Fathers, Foundering Fathers
}

\author{
Romain Graziani
}

Whichever way we may wish to nuance the observation, one cannot deny the historical fact that over time the authority of fathers in Western societies has considerably weakened, from the all-powerful status of the pater familias as defined by Roman law until the day parental authority superseded fatherly authority in most European constitutions. This development has entailed the separation of roles and functions that were traditionally ascribed to the father, seen as transmitter of a name, genitor, educator and the exclusive economic provider for the household. At first glance, it may be reasonable to assume that Chinese society has, mutatis mutandis, experienced the same process, the rise of modern times being likewise inextricably linked to the decline of the patriarchal order. For many of the vanguard writers and intellectuals who lent their voices and their writing brushes to the May Fourth movement (1919), breaking with the old, corrupt and unfair social and political order meant dethroning rulers and fathers, along with their venerated patron Confucius, ${ }^{1}$ and inverting the sacrificial relationship between fathers and sons. Although there were many social and political regimes in twentieth-century China, fathers have never recovered from these ruthless attacks, and their traditional prestige and authority have become history.

Expressed in a possibly contentious but concise formula, it could be argued that while in Europe the vision of God was shaped after the figure of the father, in China it was the father, dead or alive, who was worshipped like a god. If Chinese society never knew the mystical fever that spurred so many Christians in the Middle Ages to inflict upon themselves excruciating physical sufferings in order to reach out to God and feel worthy of his kingdom, the exaltation of filial piety in medieval China spawned blood-curdling accounts of sons ready to sacrifice themselves or their kin for the sake of their father, however unjustifiable

1. One of the earliest texts that actively contributed to make Confucius a sort of 'cultural scapegoat' for all the ills of Chinese society could well be an article by Yi Baisha 易白 沙 (1886-1921), “Kongzi pingyi” 《孔子評議》 (“Evaluating Confucius”, published in New Youth, Feb. 1916). On New Youth see below. 


\section{Romain Graziani}

or unfair the conduct of the latter might appear to us. Fundamentally, the father could not be bad or unkind, he was who he was, and wielded absolute authority.

What we are dealing with here is above all an ideological construct, and hence not necessarily "fathers in the flesh", but the father as a conceptual figure, worked out in great detail in Confucian texts on obedience. If the supreme powers in the universe, Heaven (tian) or the Way (dao), ${ }^{2}$ are not both depicted as father figures - John Lagerwey a fortiori in his contribution shows the dialectic of the Father-Mother couple in China and associates the mother figure with the Dao - one must acknowledge the 'holy triad' formed by Heaven, the Ruler (wang) and the Father $(f u)$, all being sources of life, order and authority. They generate, care for, nurture and order all living beings, and are the object of unconditional obedience and unfaltering worship. These three conceptual figures do not only fulfill similar roles on different scales (the household for the father, the earth for the ruler, the whole universe for Heaven), they also constantly define each other: Heaven is the primeval giver of life, the ancestor of the royal house of the Zhou. The Ruler is the Son of Heaven and the Father of the people, ${ }^{3}$ or more precisely the Father of all the fathers of lineage groups, the zhongfu fu. That is why, as Jean Levi translates it, "the One Man, root of all things, may be called Heaven". ${ }^{4}$ Late Warring States and Han political texts imbued with cosmological considerations repeatedly make use of analogies or metaphors to associate the Ruler with Heaven. ${ }^{5}$ Ritual prescriptions require the same mourning period and the same displays of grief for rulers as for fathers, and filial piety (xiao) is the transposition to the domestic sphere of social duties toward the ruler, which thus reinforces the parallel between the figures of the ruler and the father.

As for the father, he is in charge of religious and practical matters, and can be seen as a ruler in his household, which he 'covers' and nurtures like Heaven; ${ }^{6}$ as head of the family, not only is the father the legitimate ruler of the household,

2. In his wide-ranging article, John Lagerwey takes as a starting-point this crucial difference between the mother and father figures in Western and Chinese systems of thought and religion.

3. As well as their mother, as Jean Levi points out in his study of the evolution of the political rhetoric of the Warring States period. It should be noted that the analogy between the father and the ruler should not be construed as an equivalence. Levi reminds us in his contribution of the possible conflict between the subject's duty to the ruler and the son's duty to the father.

4. Levi (2008): $39 s q$.

5. See Jean Levi's article, which analyzes Warring States and Han political rhetoric underpinned by the father figure.

6. With the proviso that if the ruler is a father for his people, a father is not entirely a ruler in his house, but only partially: “Tout d'abord parce que, à la différence du pater familias romain, le père de famille chinois n'a pas pouvoir de vie et de mort sur les membres 
he also acts as a representative of political authority for its members, and is responsible for his clan. The father is a linchpin between the domestic sphere and the public space, and projects into his private domain the values and norms which regulate society at large. He stands at the junction of the state, seen as an assembly of all families under Heaven, and his own family, seen as a micro-state which falls under his jurisdiction.

The clear discrepancy between the Father as a symbolic bearer of authority who commands unconditional obedience and fathers as real individuals who are sometimes weak and sometimes strong, and exert their influence in the household with varying degrees of success, points to a first observation: In Chinese ritual, political and philosophical literature, fathers are primarily discussed and debated as names, as metaphors of the law and as a set of functions. The father refers to a biological role (genitor), and also to a legal status and a social function (pater) in handing down his name and property. ${ }^{7}$ The father per se, as a pivotal point in an intricate network of duties, relationships and hierarchies, evidently overshadows the father in the flesh. ${ }^{8}$

The character $f u$ 父 that designates the father, among many other things, depicts a hand wielding a stick, or maybe another object such as a weapon, symbolically invested with power and authority. Taken as a whole, it may encapsulate in a meaningful synecdoche the father as a chief and an instructor. Xu Shen, the author of the first etymological dictionary of Chinese, which was presented to the emperor in $100 \mathrm{BC}$, offers the following definition: "A norm. The head of the family guiding and instructing. Formed by a hand holding a stick."

de sa maisonnée, car les affaires domestiques sont du ressort de l'État", notes Jean Levi, who takes into consideration the legal documents unearthed at Shuihudi.

7. Freudian psychoanalysis revealed another aspect of the father which I shall not pursue here, since it would take us too far afield: an unconscious function that shapes the identity of the subject and which is to be carefully distinguished from paternity. The father figure in Freud's work is approached from a relational perspective, namely the relation of the son, or the daughter, to the father. This relation, underpinned by a mechanism of identification (Vateridentifiezierung) accounts for the CEdipal dimension of the subject. Not only is the relationship with the father a pivotal element in piecing together the subject, but the 'father' is also the name of the incarnation of an ideal and a Law, an absolute value which in China may account for the demented acts - or accounts of acts - of filial piety that reached a peak in late antiquity. On the father as Law see Freud (1939).

8. Benveniste analyzes the concept of paternity and observes that the word pater always refers to God and not to the real father who rears his child. Pater is not a matter of physical paternity: the father in his nurturing role was referred to as atta in archaic Latin. The father as pater is defined by his sacerdotal function, linked to a cult of the dead. He serves the dead and sees to it that they do not starve. The dead father, the ancestor, owes his survival to his living sons. See Benveniste (1969): vol. I, book 2, chap.1. 
What evidently prevails here is not the father as genitor but as a person of superior status, seen as a master and a guide. In this first explicit etymological definition given for the character $f u$ the pater evidently overshadows the genitor. The etymology of the character $f u$ captures fatherhood as a moral and social function more than a biological one (although, naturally, this does not preclude any other diverging interpretations drawn from later uses of the word in texts, which should in no way remain subservient to the original image forming the graph).

\section{$F u$ 'father' as a function}

From a social and religious perspective, the father acts as a linchpin in the lineage, a vital link between the living and the dead, the ancestors (= forefathers) and the descendants. He is the only person entitled to perform the rites and ceremonies to the ancestors and only in case of absence is another member of the family granted the temporary right to replace him.

Robert Gassmann, who reminds us of "the enormous prestige and great structural importance" of fathers in early China, shows the limitations of the traditional lexicographical explanation of the character $f u$ (父) ("honorific suffix attached to names of high-ranking men" or simply "elderly man”). He explains that $f u$ marked a function, in other words it was not merely honorific but an actual title which was given for life and could not be revoked. Using a wealth of data from early records, Gassmann proceeds to explain the conditions, circumstances and procedures for the bestowal and transferral of $f u$ as an honorific title. What exactly was the semantic extension of the suffix $f u$ (父 or 甫) in ancient Chinese names? Gassmann demonstrates that in some instances the term fu could not have referred to the father himself but to relatives belonging to the same generation as the biological father. The word fu could refer to the father's brother or uncle, or a cousin from the same generation as the father (or a preceding generation). In imperial history, the word $f u$ was given to princes who carried the same (sur) name as the Son of Heaven and were born before him. $F u$ not only refers to a large category of elders in the kinship system, of which the 'father' is but a particular instance, but is also an honorific title, sometimes used in a trade name (for example, yufu, fisherman, or tianfu, ploughman).

In the Zhou period, $f u$ is not a singular place in the family, says Gassmann, but a position in the lineage. "The bearer of this suffixed name form belonged to the generation preceding that of the current chief of a lineage (zong) though we can still wonder whether all the members of the elder generation, i.e. all (paternal) uncles, were entitled to this form or not." It seems, at least in the cases studied by Gassmann, that "the honorific, in this case, is restricted to the eldest living brother or paternal uncle. Younger uncles may be granted this suffix 
after the death of an elder brother thus named." The first granting of that title could have been decided upon the occasion of the birth of a successor for the man who was head of the lineage. After the demise of the first supplementary 'father', this honorific title was transferred to the living uncle born next, in order to ensure the continuation of the $f u$ or 'godfather' function; it should be noted, however, that kinship was not even a necessary condition for someone to be designated as godfather, even if members of the same kinship group were obviously preferred. The semantic discordance between our modern understanding of the term 'father' and the archaic notion of $f u$ in China is also evidenced by the fact that there could be more than one bearer of the suffix $f u$ at a single time, though usually one of these 'godfathers' took precedence over the others.

\section{The classical patriarchal system}

Is it possible to deduce from Robert Gassmann's inquiry that the role of a father in his household served as a model, by virtue of a semantic extension, for many other social functions, such as counselor to rulers or ministers of high rank? Or should we assume, on the contrary, that the functions fulfilled by a father in his household were simply specific examples of a broader set of $f u$-related functions that were in no way derived from paternity? In the latter case, we would have to infer that there was no specific word in the Chinese of that period to designate a father, just as in traditional Chinese law there is no term that exactly translates parricide, as demonstrated and discussed in Jérôme Bourgon's article. As soon as one refers to the father, one is dealing with symbolic functions and social norms that keep the genitor as an individual at a distance. If the figure of the father is 'steeped', as it were, in symbolic elements, it is evidently because blood ties, religious functions and political authority were all structured on the matrix of the family headed by the father. The political, economic, legal and cultural modalities of the father's domination, reinforced by the moral tenets of Confucianism, formed what we may call the classical patriarchal system, which proclaimed the superiority of seniors to juniors and males to females. In this system, the father who possessed male progeny, who governed his household like a wise ruler, performed his ritual duties and ancestral sacrifices with reverent care, and held a public charge at the service of the ruler, was the paragon of morality, the paradigm of human achievement, a true junzi. In the harmonious family picture promoted by the Confucian tradition, the father appears as a wise, mature, strict but well-intentioned master on whom wives and children depend entirely, as they will remain subordinate for the rest of their lives, and never be able to determine their own fates. The anthropologist Françoise Lauwaert, who has worked for years on fatherhood, filiality, transmission, adoption, and more recently on 
familial crimes, refers to the 'paternal fanaticism' (intégrisme paternel) in which Chinese society was steeped during the late classical period (her sources are mainly Ming and Qing). ${ }^{9}$ The authority of the father was unlimited, in spite of legal constraints meant to protect the rights of the son. By simply accusing his son of lacking obedience and reverence, a father was granted permission to beat him, or could have him punished by the court.

This patriarchal system seems also to have prevailed in Japanese society, and was significantly supported and exalted by the imperial ideology during the Meiji era (1868-1912). The father was emphatically defined as the head of the family $(k a c h o ̂)$, the source and model for political authority. The emperor himself compared a ruler's relationship with his subjects to that of a father with his children, and was said to love his subjects like infants (the term used was sekishi, 'imperial child', a term already to be found - in its Chinese reading - the Mencius). ${ }^{10}$ But was not reaffirming the father as the legal head of the ie and of the family a strategy to eclipse a much less rigid reality? Might it be that the figure of the father wielded influence and commanded assent mostly on paper? Emmanuel Lozerand in his paper questions the overall description of the Meiji era as a 'patriarchal system' by examining literary sources that provide a very different picture of fathers in twentieth-century Japanese society.

\section{Fathers in the flesh}

The pioneering French sociologist of China, Marcel Granet, took it for granted that no affection or kindness existed between relatives. But what do we know about the physical distance marked by parents toward their children, crucial as this distance may have been in the need to secure their compliance to ritual behaviors? To what extent was a certain degree of informality tolerated? It is highly likely that many families strayed quite seriously from the canonical models of filiality depicted in the collections of stories of pious sons circulated in China, and later in Japan. Today, a historian can no longer take these ritual prescriptions and moralizing tales at face value. The edifying examples of filial piety were part of an enterprise that sought to control, regulate and ultimately shape the conduct of later generations. They do not tell us how children actually behaved, but how a certain elite thought they ought to behave, and they also give us an inkling of the kind of ideal that gradually became ingrained not only in the establishment but (if we judge by the popularity of the textual and iconographic records) in people at all levels of society.

9. See Lauwaert (1999): passim.

10. Mengzi, 5A “Teng Wen Gong, shang”騰文公上. 
Indeed, many of the contributions in this volume nuance or contradict the one-sided vision of powerful and severe patriarchs ruling their people. Some authors, such as Emmanuel Lozerand and Jean Levi, highlight the weakness or the deceitful character of the paternal institution. Other authors rehabilitate the father as a caring person (on the biographical or the ideological plane) living in emotional proximity to his kin. Mark Lewis focuses on the emotional aspects of Chinese households in the early imperial period.

The image of the father mirrored in legal codes, moralizing discourse and ritual compendia is often that of an authoritative, threatening and distant figure. But although a family forms a political and religious system, we need to remain aware of the differences between family as an institution and family as it is experienced daily by its members, as a private sphere imbued with personal feelings, emotions and singular dispositions creating a complex network of intersubjective ties. Allow me to quote one example: in one of his poems entitled, "Two Charming Little Girls", ${ }^{11}$ Zuo Si (ca 250-305) depicts with an irrepressible tenderness his two daughters playing games and doing their homework. This poem may be an exception in Chinese literature (although its apparent uniqueness might be due only to a contingent cause, such as the uneven preservation of written records), but the poet's feelings for his two daughters were certainly not unique. ${ }^{12}$ Nicolas Zufferey in his article adduces another touching illustration of the unconditional love of a father for his daughter, in one of Jin Yong's novels, The Eagle-shooting Hero. This love is so strong that Jin Yong indirectly confirms Han Fei's warning about the dangers of showing too much love as a parent: "In no way did he try to restrain his feelings for his daughter, whom he loved more than his own life. He spoiled her so much that she became capricious and disobedient." 13

This chasm between ritual distance and affective ties in the household has been frequently explored in recent sinological publications but the papers here by Mark Lewis and Keith Knapp provide a fresh perspective in this field of study, and give us a heightened sense of the discrepancy between the ideological figure of the father and the father as he appears concretely in his household and behaves towards his progeny.

11. The poem was preserved in chapter 2 of the anthology "New Songs from a Jade Terrace" or Yutai xinyong 玉臺新詠, compiled by Xu Ling 徐陵 (507-583) during the mid-Liang period. See Sibu beiyao II-16b or LU (1983): 735; or for a more accessible edition, the 1985 Zhonghua reprint: 90. For an English translation of the poem, see Birrell (1982): 85.

12. My thanks to François Martin for drawing my attention to this poem, which I had not come across previously.

13. Jin Yong (1985): chap. 10. 
How, for instance, should we interpret the widespread canonical image of parents, consisting of a strict and aloof father and a loving, caring mother? Three authors tackle this thorny issue. Emmanuel Lozerand adduces biographical details, legal elements and literary materials to nuance our vision of Japan's patriarchal society prior to World War II. He shows that our vision is in part biased by the official discourse on paternal authority: it was precisely when the father's authority and prestige began to decline that the imperial government refurbished his image in a strongly assertive response to his decreasing prestige. By contrast, the foibles and faults of the father are obsessively brought to the fore by major authors of the time, such as Natsume Sôseki in his most famous novel Kokoro (1914).

Keith Knapp, for his part, reminds us (with an eye to criticizing it) of the commonly held view that "in pre-modern China the father-son relationship was always marked by formality and emotional distance. No less an authority than the philosopher Han Feizi ( $c a$ 280-233 BC) underscored that this was indeed the case... In other words, mothers smother their sons with love, while fathers remain aloof from them and enforce discipline. But was the father-son relationship so devoid of sentimentality and intimacy?". While Mark Lewis examines the emotional, social, and symbolic importance of the mother-son tie in medieval China, Keith Knapp's article focuses on the father-son relationship, and comments on unusual depictions of the father figure during China's early medieval period (100-600). Drawing on written and iconographic sources, he analyzes images of fathers in a nurturing role, sometimes even breastfeeding their offspring. So much for the rigid attribution of roles confining the father to a distant position marked by ritual strictures. In these striking scenes where sons suckle at their father's breasts, the mother is expectedly absent, the father having taken over what seemed to be her irreplaceable function and physical intimacy with her son. Now the father is sufficient to care, nourish, and educate on all levels. ${ }^{14}$

However informative these accounts of filial piety may prove for our exploration of early Chinese society, one naturally cannot take them at face value. One has to wonder why they were written and circulated, which trends and tendencies they were intended to counter, and what could be their impact and popularity in society at large. It is not difficult to perceive what is at stake in

14. We are not implying here that accounts of filial conduct negate the mother, indeed quite the opposite: Keith Knapp's careful exploration of xiao-related textual and visual materials indicates a wider number of tales depicting pious conduct toward the mother. The paediatrician and psychoanalyst Donald W. Winnicott noted that the father must in no way be a replica of the mother's image, and that he does not have to replace her. 
this proliferation of pious tales. The danger of loss of prestige and authority may have accounted for the circulation of stories extolling the virtues of filial piety and stimulating the sense that the interests of both fathers and sons were served by the relationship of subordination of the younger to the elder, since the son will become a father and must also secure the hierarchical order which will guarantee him support and care from his own children. Regarding the reciprocity which is seen as the foundation of the parent-child relationship, Keith Knapp comments in the following terms on the story of Yuan Gu, one of the most frequently illustrated stories of filial piety between the Eastern Han and the Yuan dynasty: “... Men sometimes viewed their unproductive and frail fathers as a drain on family resources and an impediment to raising their own family. Through remonstration, Yuan Gu reminds his father of the reciprocity that is the foundation of the parent-child relationship: men take care of their elderly fathers' needs because they expect the same behavior from their sons. This tale simultaneously indicates that a key aspect of fatherhood was setting an example for one's sons - sons would behave the same way their fathers had."

The emotional bonds between parents and children are typically evoked from the standpoint of the children. Who the father really is, or the reasons for his often unjust behavior, remain unquestioned, and thus unknown. As readers we are never privy to the father's or the (step-) mother's thoughts, which may account for their unseemly foolishness or cruelty. What matters is the edifying illustration of the tenacious efforts, the pious dedication or the enormous sacrifices the children make out of love and respect for them, however irrational or perverse these parents may appear. As such, narratives of filial piety constitute an ideological bulwark defending hierarchy and seniority, and a powerful moral spur to elicit a repertoire of conduct ranging from blind imitation to wise emulation. The absolute obedience fathers commanded was a shield against the vulnerability of old age, when they could no longer wield their authority and impose their writ. Han Fei recalls that it is hard to find a son willing to risk his life to save his father, and says there may be one in a thousand, at best. ${ }^{15} \mathrm{He}$ also reminds naive moralists that relationships between parents and children are governed by the driving force of personal interest, hence the frequent killing of baby girls, since they cannot be counted on for future economic support. ${ }^{16}$ The strong emphasis placed on the necessity for unconditional obedience must have put a heavy strain on sons and daughters who were not prepared to adhere to the official creed. Filial piety required grown children to provide financial assistance, respectful care, and a lavish funeral (followed by a prolonged and debilitating mourning

15. Han Feizi: “Refutation, 2", 37.369 (“Nan er” 難二) .

16. Han Feizi: “Six Reversals", 2", 46.417 (“Liu fan”六反). 


\section{Romain Graziani}

period) for their parents, as well as a male descendant for the perpetuation of the ancestral cult and the name of the clan. Above all, they had to acknowledge the absolute primacy of their parents' needs and desires, superseding even the lives of their own children (think of the tragic example of Guo Ju, ${ }^{17}$ who out of filial piety buried his child alive, though such infanticide must no doubt have aroused a very skeptical attitude in many Confucian scholars). The pervasive presence of harsh constraints imposed by filial piety are inversely proportional to the quasi-absence of moral justification for such extreme behavior. Authors apparently did not feel the need to expose the rationale, if indeed there were any, underlying these attitudes. The feeling of indebtedness which all these duties maintained throughout a person's life plays a crucial dramaturgical role in many accounts of filiality. ${ }^{18}$ In these narratives, the desire to pay one's debts conjures up threatening situations in which parents must be succored, rescued, even resuscitated and brought back from the world of the dead, sometimes at the expense of children who undergo excruciatingly painful ordeals.

Paying one's debts to one's father, at the expense of one's own fatherhood, is a situation that partly accounts for the tragic choice made by Sima Qian ( ca 145-90 BC). We may even contend that the figure of the father and the feeling of indebtedness haunt his whole work. In 104 BC, Sima Qian began to write his monumental narrative of China's history, starting from the legendary period, but five years later he infuriated the Emperor Wudi (r.140-87 BC) by advocating the cause of General Li Ling, who was accused of high treason for having surrendered to the Xiongnu. Sima Qian was left with the tragic choice of drinking poison or accepting castration (in principle he could have bought off his punishment but in fact could not afford it). In his memorable letter to Ren An, one of the most beautiful texts ever written, the historian explains he preferred the humiliation of being castrated to an honorable death, in order to live up to his father's injunction and pursue the historical record he had begun. ${ }^{19}$

The question of the father-son relationship may indeed prove to have a considerable bearing on the understanding of many narratives in the Records of

17. The famous story of Guo Ju 郭巨 in Guo Jujing's Xiaozizhuan 孝子傳 (Accounts of Pious Sons).

18. Of course, one could escape the inescapable by becoming a Buddhist monk: this released one from the duties imposed on sons and subjects of the empire.

19. How much of the Shiji the father, Sima Tan, had written remains a moot point. On Sima Qian's letter to Ren An, see Fuehrer (1997): 170-183; Knechtges (2008): 75-84; Goldin (2005): 179-182; for the most recent and valuable scholarship on this question see Esther Sunkyung Klein's doctoral dissertation, History of a Historian: Changing Perspectives on the Authorial Roles of Sima Qian, chap. 4, 5 and especially 8. 
the Grand Historian, initiated as it was by the father, and continued by the son as a pious obligation. ${ }^{20}$ In presenting his vast portrait of China, Sima Qian was abiding by the will of his father Sima Tan, but also as taishi gong or "duke grand scribe" he also had to heed the command of Emperor Wu, who pardoned him in $96 \mathrm{BC}$ and promoted him, after his shameful punishment, to private secretary, a position restricted to eunuchs. Sima Qian finally completed the Shiji in 91 BC.

The author of the first history of China may be seen in this respect as the sonless servant of two fathers: serving his genitor by continuing his work, while also serving the emperor, the arch-figure of the father on the symbolic and political level. Simultaneously, in the process of writing, Sima Qian exacts revenge on the author of his misfortune. ${ }^{21}$ Since Han Wudi is the father of the people, we may construe this literary chastisement as a symbolic parricide. By this covert retaliation, the historian excoriates the supreme Father, who by meting out castration to him deprived him of a male descendant and debased him by making him an eunuch. Why Sima Qian did not write the announced biography of Emperor Wu will always be open to speculation, but there is nothing to prevent us from seeing that one of the outcomes of this absence is, on a textual plane, an annihilation: he edits out the very person who has sponsored his historical work and is the supreme recipient of it. ${ }^{22}$ Emperor Wu is, however, criticized in the guise of other characters, in particular the first Qin emperor, with whom Sima Qian implicitly draws many analogies. The famous tale of King Goujian of Yue, who harbored a grudge for years, and suffered humiliation in silence before taking revenge on $\mathrm{Wu},{ }^{23}$ or the stories of wandering knights

20. Esther Klein, in the dissertation quoted above, analyzes how Sima Qian's personal tragedy was perceived by later authors, and how it was thought to have had a bearing on his work as a historian, first unfavorably, and later, from the Song onwards, in a more sympathetic fashion. She also shows pertinently what part later reconstruction plays in our modern perception of the martyr historian.

21. See Levi (1995): 140-160, esp. 144-147; see also Schaab-Hanke (Oct. 2012), who analyzes a few passages of the Shiji drawing on the Gongyang zhuan, in which Sima Qian implies that Emperor Wudi is not by a long shot the wise ruler who had been expected by Sima Tan and then himself. While this textual 'dynamite', as she sees it, may be part of a subtle act of treason, it may also be seen as a kind of textual reprisal against the man who ordered Sima Qian's punishment.

22. It should be nonetheless reminded that the composition of the Historical Records was a private, or semi private, enterprise. In no way were the Shiji composed at the behest of Emperor Han Wudi.

23. The gist of this story is encapsulated in the proverb (chengyu): woxin changdan 臥薪嘗 膽. On that story and the proverb appended to it, see Cohen (2009), who chronicles the rhetorical uses of this tale in modern China and analyzes a recurring pattern of sentiment in Chinese culture. 
and mercenaries defeated and humiliated are eloquent instances of Sima Qian's propensity to identify with those who had been harshly punished, tortured and enslaved by a ruler. The same medium that enabled Sima Qian subtly to vent his grudge, was also a remedy for his barren and crippled body: by replacing procreation by creation, by bringing to life so many characters who without his brush would have sunk into oblivion, Sima Qian secured his name, and gained both a reputation and a flourishing intellectual progeny. In this respect, we may view him as the Father of history.

\section{Lacking and tracking the Father}

Rainier Lanselle's contribution to this volume reveals the pervasive and haunting presence of the father figure in Pu Songling's masterpiece, the Liaozhai zhiyi, as clearly evinced in his preface (zizhi), and examines the symbolic aspects of fatherhood from a psychoanalytical perspective. Indeed, scholars have hitherto underrated the question of the father as a symbol and as a function in $\mathrm{Pu}$ Songling's work and in reflections on his literary activity. Lanselle's careful reading and translation of Pu's preface show how the author fleshed out a symbolic father through fantasies and images revolving around the figure of the dead father and his own feeling of indebtedness. In Pu's account of a strange dream, recorded in the preface, the father appears only in the form of a black mark on the chest of the author (who in the dream is a gaunt and wizened monk) and makes him aware of a fundamental lack. What is the father, ultimately? It is a name, and that name resonates as an absence, a founding absence, if we may put it that way, since it is an essential element in the formation of the author's subjectivity: the physical trace on the nipple, a black stain left by something past, is also the ink from which will surge forth all the ghost stories that will form the book. The mark of the father on a gaunt Buddhist monk simultaneously reveals a castrated desire and a sense of indebtedness toward the father. Castration and debt: these two pivotal elements in the author's psychology, so baldly expressed in Pu's preface, are a remote echo of Sima Qian's situation in his own time. But what exactly is the nature of this debt? Is it something of which every child should be mindful, or is it merely the consequence of a situation specific to China, in which filial piety fulfilled crucial economic and social functions? The issue of filial piety has over the past decades surfaced in Western philosophical debates. The increasing needs of an ever-aging population, economically supported by their children, have brought to the fore the question that is central to the legitimacy of filial piety: what do children, once grown, owe their fathers and mothers? Do we owe something by nature to our parents, and what is the duration and extent of our duties towards them? Is the 
obligation imposed on grown children to take care of their parents, to love them and even make sacrifices for them only conditional or is it absolute? Does it depend, for instance, on the children's evaluation of what and how much they received from their parents during their childhood? Can a grown child be the sole judge of what he owes his parents? Do we pay our debts, or act purely out of love and charity? ${ }^{24}$ Jeffrey Blustein's theory of Gratitude distinguishes between owing and being indebted: there are duties of gratitude and duties of indebtedness. Duties of gratitude concern persons who have benefited us freely, without any motivation of self-interest. For Jane English, ${ }^{25}$ there are no more obligations toward one's parents than there are to friends or people we love in general. In short, there is no essence of filial duty. If parents are loved and respected, they will be taken care of, but they cannot claim the right as parents to be provided for (even if the law sees this situation from a different angle). For Raymond Belliotti, ${ }^{26}$ on the other hand, we do have moral duties of a specific kind toward our parents: filial obligations are underpinned by the fact that our parents have shaped our identity, and so we are necessarily bound to the ones who made us become what we are. In caring for our parents we thus remain faithful to and consistent with what we are. This position is quite untenable for many reasons, among which are the problematic definition of identity and the possible negative contribution of parents to what we are.

If today in this debate we find many authors of Chinese descent championing traditional filial piety against an often caricatured Western egoistic conception of the subject, we should nonetheless recall that Chinese intellectuals at the turn of the twentieth century associated modernity, progress, science, and democracy with the destruction of the old corrupt and cruel patriarchal system. Among the reformers of 1898, Tan Sitong (1865-1898) and Kang Youwei (1858-1927) contended that the family as a hierarchical system should be abolished, and that there should be no more rulers. Yan Fu (1854-1921), who translated and introduced Herbert Spencer's views on evolution and his theories of social Darwinism, held China's patriarchal and ritual system to be responsible for its becoming a backward nation in the twentieth century. In his study on China and Charles Darwin, James Pusey showed that Darwinism acted like a catalyst for criticisms of patriarchal society. Whereas filial piety taught children to conform to their ancestors' will lest they should become degenerate, Darwinism showed younger generations that adaptation, change, and reform were vital for their

24. See O'Neill and Ruddick (1979).

25. See English (1979): 351 sqq.

26. See Belliotti (1986): 152 and Belliotti (1988): 288; both articles are quoted and their arguments discussed in $\mathrm{Li}(1997)$. 
survival in the modern struggle between predatory nations. In short, if one wanted to secure a future and a progeny, one had to rid the world of fathers and forefathers.

The May Fourth movement, unlike the Revolution of 1911, was not an uprising against a crumbling dynasty, but a fiercely critical charge against the ideological frame of the empire itself. In this rebellion, Confucius, as the tutelary figure of this crushing patriarchal dispensation became the paradigmatic father figure to topple. He came to stand for all the oppressive and cruel social practices (foot-binding, enforced chastity, absolute obedience) which were retained solely for the pleasure and benefit of fathers and leaders.

$\mathrm{Lu}$ Xun was one of the leading voices in this moral revolution that led to the jettisoning of time-honored representations and their replacement with new paradigms inherited from Western science. Traditionally, the further back, or the older, the ancestor was, the more prestige he had. The vertical axis placing forefathers before and above their descendants, in a deliberate confusion of chronological level and scale of values, had to be replaced (according to Lu Xun) by the biological model of cellular regeneration. ${ }^{27}$ In this new paradigm, it is not the case that everything ancient is eminent and awe-inspiring, it is merely antiquated and decrepit. In a speech delivered in 1927 (just before Jiang Jieshi's coup), Lu Xun compared people who cleaved to ancestral standards of conduct to primates refusing to evolve. Those who remain in submission to the power of ancestors and fathers are no more than apes, unable to stand up and walk on two feet. One becomes a fully-fledged adult by cutting loose from the patriarchal order. In "How to Be a Father Today", Lu Xun exhorts the younger generation to invert the almost sacrificial relationship between parents and children and replace rigid duty by genuine love. Between a father and a child, he says, there are no debts (fu zi zhi jian mei you en).

Lu Xun was not alone in perpetrating this 'cultural parricide'. Many angry sons of the 1919 generation vented their grudges against the political, social, economic and literary oppression of Fathers. In several articles published in New Youth such as "On the Kinship System as the Foundation of Tyranny", "About Filial Piety", and "Cannibalism and Traditional Mores", ${ }^{28} \mathrm{Wu}$ Yu (1871-1949) lists all the terrible acts carried out in the name of filial piety against the people, among them infanticide (baby girls buried alive or drowned), self-mutilation and

27. Chen Duxiu held similar views in the inaugural text of the journal New Youth (Xin Qingnian 新青年) he created in 1915 in Shanghai, Jinggao qingnian 警告青年 ( ${ }^{\circ} 1$, Sept. 1915).

28. See the bibliography for the references to the Chinese texts. 
arbitrary repudiation. He depicts a society enslaved by the will of dead people, producing cringing, cowardly and barren beings.

Wu Yu, Ba Jin in his famous novel Jia (Family) (1933), and Hu Shi (18911962) among others excoriated the concept of filial piety, and denounced the instrumental role it played in perpetuating unquestioned governmental authority, thus producing citizens incapable of any original ideas, and thereby blocking China's path toward modernization. They also emphasized the fact that filial piety, with its prescriptions of absolute obedience and loyalty, eliminated any desire to protest or rebel against patriarchal society. The father, wishing his son to be filial, obtains his submission by fear and physical coercion, after which the son is reduced to a mere beast or a slave.

Lu Xun recalls the pangs of anxiety which seized him when listening to the story of a filial son who without hesitation buried alive his own progeny for the sake of his parents. "If one wants revolution, one must overthrow elders and fathers". ${ }^{29}$ In his article "How to Be a Father Today" (Women xianzai zenyang zuo fuqin), he evokes a smarting memory from his childhood (he was seven years old at the time), when his father prevented him from attending the Five Devils carnival (wuchanghui) until he had learnt by heart and was able to recite a particular classical text. Lu Xun's frustration became so intense that when eventually he got to the carnival, the sense of festival joy had died in him, and all the pleasure was spoiled. It is significant here that the paternal figure's tyrannical authority is associated with the restrictions of a classical education in wenyan. The constraints prescribed by the father can be seen as the projection within the family of the strictures imposed by the classical literary education. Lu Xun takes a stand against both the classical language and his father's voice, the latter being the mouthpiece of the former. In this context, it might be easier to understand how the symbolic father of Chinese culture, Confucius, could be the devil incarnate in the eyes of the protesters of the May Fourth movement. Naturally, both Lu Xun's confession and the May Fourth protest could only be couched in the vernacular tongue (baihua), in opposition to the language of authority.

"Anything a father says is naturally right, but if the son says something, he's wrong even before he has opened his mouth." 30

29. 總而言之: 只是革命要革到老子身上罷了: this is the opening sentence of his polemical article "How to Be a Father Today?” ("Women xianzai zenyang zuo fuqin? 我們現在怎 樣做父親? ), edited in Tomb (Fen 墳), the first volume of his complete works published in 1927, in which he brings together many didactic reflections originally published in New Youth (Xin Qingnian).

30. 若是老子說話, 當然無所不可, 兒子有話, 卻在未說之前早已錯了。 


\section{Romain Graziani}

In his study of the Twenty-four Exemplars of Filial Piety (ershisi xiao), composed by the Yuan dynasty scholar Guo Jujing (14th century), Lu Xun compares different versions of the same story and points up a general trend over time to exaggerate the cruelty of the events described. ${ }^{31} \mathrm{He}$ ascribes these gradual narrative changes to the brushes of ill-intentioned authors (for instance, Teng Bodao's son, abandoned by his father, who flees with his nephew when his house is attacked by robbers, ${ }^{32}$ in a later version ends up tied to a tree!). We can easily imagine Lu Xun being alternately infuriated and appalled when examining the long history of perverse practices associated with the reverent love and absolutely unquestioned obedience to the father: examples include sons making a wooden surrogate of a father they never knew and serving it day and night, asking the wooden block permission before doing anything; sons being suckled by their fathers, as mentioned above; sons stealthily washing their parent's soiled underwear at night; sons cutting off a piece of their own thigh to feed their hungry father; sons pulling a cart to give their mother a smoother ride than an ox would do; sons preferring to commit suicide when slandered by a cruel stepmother or wrongly accused by their father, rather than defend themselves. Keith Knapp comments with a scholar's eye on stories in which fathers, or pseudo-fathers, give preposterous or even sadistic orders - such as to build a house in the middle of a river - and provides an interpretation of these overdramatized manifestations of filial love.

Among other things he reminds us that ultimately there were no such thing as 'bad fathers' in the medieval period: "Even more telling are the stories that feature 'bad' fathers. These narratives stress that fathers only do horrible things to their sons because of their stepwives' lies. In these tales, fathers naturally love their sons, and the relationship only deteriorates because stepmothers drive a wedge between male kin. Fathers might be severe, but they also have tender feelings for their sons."

If we turn to Ming and Qing literature, we can observe a profound change in the depiction of the paternal figure. Now we have explicitly bad, evil and perverse fathers, who become the bêtes noires of many tales. In most novels and plays of that epoch, the father plays a very negative role and is often an object of sarcasm, aversion, contempt or rebuttal. ${ }^{33}$ We may discover there the origins

31. On Lu Xun's dreadful fear aroused by the reading of Guoju's story, see Knapp (2005): $1 s q$.

32. Teng Bodao's brother having died, it was a sacred duty to preserve his male descendants, and this consideration prevailed in the brother's mind over the protection of his own child.

33. I am not implying here that the father always appears as a debased or pathetic individual. There are also depictions of perfect fathers (think, for instance, of An Xuehai in Wen 
of the harsh criticism of paternal authority that culminates in the May Fourth movement. ${ }^{34}$ In that sense, twentieth-century intellectuals merely radicalized and extended criticisms that were born within tradition: rebellion against paternal authority is not necessarily the hallmark of modernity. In most stories depicting family life in a realistic manner, the father appears in a very negative way: he can chiefly be characterized by his excessive severity and cruelty, by his sexual wantonness and debauched behavior, or by his cowardice and his inability to assume his responsibilities. He can also appear as an avaricious miser, or even a criminal. Many authors insist on the moral oppression exerted by the father as an educator. What is supposed to be 'paternal rationality' in fact impairs the children's sensitivity. The father's severity often entails a burst of sadistic violence, and he sometimes goes so far as to beat his son to death, as in Bo Xingjian's (776?-826) Tale of $\mathrm{Li} \mathrm{Wa},{ }^{35}$ in which the father, Xingyang Gong, kills his son after finding out he is leading a depraved life in a house of ill-repute and has spent all his money. Such fathers can be found in many tales from the Song and Yuan periods. These vernacular stories (huaben) abound in cruel fathers; among them let us quote as most notorious examples the rich merchant Zhou Dalang in Love-lorn Zhou Shengxian Wrought Havoc in Fanlou, ${ }^{36}$ a sort of parody of the Peony Pavilion; Minister Pei Xingjian - Pei Shaojun's father - in Riding by the City Wall; ${ }^{37}$ Ruilan's father in Baiyueting; Yuanwai Wang, or Sir Wang, (as an adoptive father), in Zhang Tingxiu Escapes from Death and Rescues his Father, ${ }^{38}$ Yang Shichang in Cui Xiangshan's (fl.1836) Baiguizhi, or Intendant $\mathrm{Ke}$ (Ke Taipu) in Tingyuelou. One of the most famous examples is surely Du Bao in the Peony Pavilion (Mudanting) who lets his ailing daughter die without inquiring about her fate, and later, when he finds her resuscitated, writes a request to the emperor to be granted permission to flog this devilish creature

Kang's 文康（fl.1842-1851) Biographies of Heroic Sons and Daughters (Ernü yingxiong zhuan 兒女英雄傳), but I am focusing here on the criticisms of the father that seem to appear at that time.

34. We can already observe, in many classical novels, attacks against characters who exercize authority in a patriarchal fashion: see for instance Song Jiang, the bandit leader in Water Margin (Shuihu zhuan 水狺傳), or Tang Seng, who is like a father in The Journey to the West (Xiyouji 西遊記).

35. Li Wa zhuan 《李娃傳》.

36. Naofanlou duo qing Zhou Shengxian 《閙樊樓多情周勝仙》, chap. 14 of Constant Words to Awaken the World (Xingshi hengyan 《醒世恆言》). For an English translation, see Yang \& Yang (2009).

37. Qiangtou mashang 《牆頭馬上》. Another possible translation would be By the Wall, On the Horse, see Song (2004): 73.

38. “Zhang Tingxiu taosheng qiufu” 《張廷秀逃生救父》 in Constant Words to Awaken the World, chap. 20. 
(yaonie). In The Dream of the Red Chamber (Hongloumeng), Jia Baoyu's father Jia Zheng loathes his son from his first birthday and never misses an occasion to make snide remarks to him. Each time he calls his name, Jia Baoyu is in a state of panic, holds his breath and changes color. When Jia Zheng finds out his son is enmeshed in an affair with the maid Jin and vying with a prince for the favors of a young actor, he beats him severely.

With regard to sexually debauched fathers, we should mention Ximen Qing in the Plum in the Golden Vase (Jin Ping Mei), who seduces a young girl, Li Gui, and asks his wife to adopt her. He also disposes of his dead son's body without giving him a proper funeral. Jia Zhen in the Dream of the Red Chamber is also a pathetic case: not only does he partake in forbidden pleasures in the company of his son and his cousin, but he has an affair with his daughter-in-law, who commits suicide once their liaison becomes known.

Fathers can be much worse than selfish, lackadaisical or brutal when, for instance, they stoop to selling their children. In the Yuan dynasty drama (zaju) The Slave Riveted by Money, ${ }^{39}$ Zhou Rongzu sells off his son Zhou Changshou to Jia Ren. In Guan Hanqing's (1225-1302) famous tale The Injustice Done to Dou $E^{40}$, Dou Tianzhang sells his daughter Duanyun as a young girl to be married (tongyangnii) in order to cover the expenses of a trip to the capital to sit the imperial examination. In Wu Jingzi's (1701-1754) The Scholars (Rulin waishi), a certain character called Ni Shuangfeng, who in thirty-seven years progresses no further than xiucai, sells five of his children in order to cover his expenses each time he fails the higher examination (the sixth one is spared this lot because he dies).

A situation found very commonly in these novels is where the father shirks his responsibilities and abandons his household. In The Dream of the Red Chamber, Jia Jing, Jia Zhen's father, evades all his duties as a father and neglects his children in order to practice self-cultivation and become an immortal. In "Wang Benli Goes to the End of the Earth in Search of His Father", ${ }^{41}$ the eponymous character - also called Wang Yuan - leaves his wife and children and wanders for twelve years in search of his father Wang Xun. ${ }^{42}$ When Wang Yuan

39. Kan qian $n u$ 《看錢奴》.

40. Dou E yuan 《竇娥冤》.

41. Wang Benli tianya qiu fu, 《王本立天涯求父》, which is the third chapter of the late Ming huaben collection (ca 1627) The Stones Nodded Assent (Shi dian tou 《石點頭》).

42. The figure of the 'evading father' is to be found in other texts. See, for example, Ai Zicheng's 艾子誠 father in Ji Yun's (1724-1805) Random Notes from the Cottage of Subtle Scrutiny (Yuewei caotang biji, 《閱微草堂筆記》18) or Guo Xiaozi’s 郭孝子 father in The Scholars (Rulin waishi 《儒林外事》). These fathers benefit from the total devotion of their sons, but remain until the end mean and despicable individuals. 
sees that his father is determined not to return home with his son, in a burst of despair he knocks his head on the ground, lamenting that a life without a father has no meaning. Obviously, to Wang Yuan, the father is a sort of transcendent authority whose personal feelings and moral behavior do not matter. Wang Yuan's quest, ardently driven by filial piety, does not take into account who his father really is. He needs his father, whoever he is and however he may behave.

These works of fiction, including the story of Wang Benli, can be regarded as antidotes to the unquestioned canonization of the father in traditional accounts of filial piety. Fathers are depicted as failing to meet the moral standards required by their position, and unable to live up to their children's expectations. Many of them are losers, failures, thugs or perverts. One must nonetheless acknowledge the fact that the children in these stories do not detest their genitor, and do not openly rise against their fathers. They abstain from challenging their authority, and are not tempted to fight back when being beaten, or even go so far as to show themselves disrespectful or insolent. ${ }^{43}$ Even as adults, in the presence of the father they remain apparently submissive. ${ }^{44}$ When faced with a hostile and brutal father, either they accept harsh treatment, and sometimes die, or else they find a trick to stave off a direct violent confrontation. In the worse cases, they run away. In the Peony Pavilion, when his wife dies, Mengmei spits out some remarks at his cruel father-in-law, but it does not go further than that.

Yet, even in stories which have an uncritical son looking up his father as the only person capable of giving value and meaning to his existence, we can hear dissonant voices echoing the modern reader's indignation. The narrator in the story about Wang Benli may several times state his intention to exalt filial piety, but he also openly criticizes the father when he writes "Wang Xun shirking his duties reveals a blinkered mind". Wang Xun's wife, Lady Zhang, proves even harsher in her criticisms. From the very beginning of the story, she sees in her husband's decision to flee the symptom of a lack of ambition and a narrow view of things, and she scolds him for running away, and leaving her with a small baby, in charge of everything in the house. Lady Zhang later remonstrates with her son for abandoning her after all those years of toil and sacrifice, just for the sake of a father who never did anything for them. She calls into question her son's biased view of filial piety, which is solely focused on the father figure, to

43. In his article, Nicolas Zufferey gathers many examples drawn from contemporary novels of neglectful fathers stung by remorse and guilt, and of sons and daughters standing head to head with their father, giving free rein to their grudges and their intensely negative feelings.

44. The legal context also explains why children dared not talk back to their fathers. Harsh punishments were meted out to anyone who showed disrespect to his father. See Jérôme Bourgon's article, and also Lauwaert (1999). 
the detriment of a caring mother. Another character, the Buddhist monk Fa Lin, lends an authoritative voice to the criticism of the irresponsible and selfish father. He chides Wang Xun, proving to him that he has behaved like a bad husband when he refused to stay at home, and is now acting like a bad father in refusing to return home. If to Wang Benli's mind, his father is Heaven, in the eyes of Lady Zhang and Fa Lin, Wang Xun is just a narrow-minded, apathetic person. In this criticism of patriarchal culture, the lesson is doubly cruel: not only does blind imitation of filial piety lead to the veneration of tyrannical and unworthy fathers, it also leads grown sons to become bad fathers themselves and in turn hurt other people in the household. The spouse and the monk reveal the father's cowardice and strip him of his halo. As to the son, we see him gnawed by guilt and remorse. This is a widespread critical position in fiction, particularly in the vernacular language, by the end of the Ming.

Encouraged by these explicit criticisms of the father expressed by protagonists in the story, the reader can observe for himself the havoc wreaked by the defective head of the family. He does not necessarily need the intervention of a superior authority in the story (a judge, a monk or the emperor) to learn who is right and who is wrong. He becomes aware of the critical overtones intended by the author and becomes the sole judge of what is being shown and done in front of his eyes. ${ }^{45}$ Nicolas Zufferey analyzes the complex repertoire of attitudes toward the father in the literature of today. Exploring a large sweep of modern Chinese fictions, he contends that the opposition between a "grand literature" championing liberation from tradition, progress, and individual rights and, on the other side, a popular literature still swaddled in patriarchal values does not really hold today. In fact, many contemporary novels, in no way avant-garde, have a more adequate perspective on real society, depicting old family values and modern Western-inherited conceptions of the self as constantly overlapping, and casting young protagonists as sometimes submissive to and sometimes in revolt against the father figure. Zufferey shows, for instance, the pervasiveness of the notion of debt in parent-child relationships. Many protagonists from Jin Yong's novels restrain themselves from killing their fathers, even though they know they have raped and killed. The coercion of duty goads children into a forced but resentful passivity. Children must return what their parents gave them (bao, the concept of reciprocity), even when they clearly feel they are not the fruit of a loving union.

45. We cannot deal here with the complex question of the authorial voice criticizing one of the characters. 


\section{The inconsistencies of the fatherly Ruler}

If Ming and Qing literature with an acute and reproving eye draws our attention to the misdemeanors of bad fathers in novels that could be seen as the harbingers of the 1919 uprising against the paternal order, we may trace the criticism of the political and social paradigm of the father back to a text as early as the Han Feizi. The father seems to have been inadequate in his symbolic role from the start. Han Fei (d. 233 BC) repeatedly states that the father cannot be taken as an example of governance and authority. The Confucian-oriented analogy between the father and the ruler should be rejected when one understands the true nature of sovereignty and the real relationship between a ruler and his subjects. Han Fei grants the possibility of an analogy between the pious son and the loyal subject, but not that between a ruler and a father. The analogy only holds to the extent that an expectation of absolute obedience is concerned. In chapter 46, "Liu Fan", the enlightened ruler rejects the canonical model of the wise father and the loving, caring mother. The father's relentless rigor is more efficient than any display of affection could be. The only admissible analogy to be drawn is with a stern father who beats his children. In chapter 49, "The Five Vermin ${ }^{46}$ ", the author reiterates this argument and chapter 50, "Illustrious schools" ${ }^{47}$ once again lampoons the analogy between the ruler and the father-mother couple. Why precisely father and mother? Jean Levi shows the gradual deficiency of the father in the construction of political authority. The mother, endowed with all the feminine qualities that texts later classified as Taoist or as military strategy promoted in their rhetorical onslaught on the patriarchal order of the old Zhou society, had to succor the father. Her secret potency backs up his foundering power. Jean Levi demonstrates changes in late Warring States political discourse and comments shrewdly on them: the ruler is not only the father of the people, but suddenly becomes the father and mother of all beings. Political thinkers and statesmen muster all the motherly and feminine qualities (dark, supple, flexible, humble, water-like) to rescue an imperiled fatherly figure. With the Laozi the mother becomes the arch-genitor, the source of all living things. In medical literature and self-cultivation texts, the Great Mother nurtures and fosters not only her baby but her mate, who during their sexual intercourse restores his vital forces. Terms coined for the first time in the Laozi (deep valley, mysterious gate) are endowed with a very concrete meaning, referring to the genital organs of the female body. Women are considered and valued for their power to give life, while some thinkers (as evinced in the Mawangdui manuscripts appended

46. “Wu du” 《五冨》

47. "Xian xue"《顯學》. 


\section{Romain Graziani}

to the Laozi) disparage the image of the active domineering father and value the female over the male, or the hen at the expense of the rooster. If we follow Jean Levi's inquiry, we can see clearly how the patriarchal model is supplanted by the parental one. The mother fills the father's boots but maybe only the better to fulfill his desires and worldly ambitions. This last consideration brings us back to the final centuries of the imperial period, where often in tales depicting fathers running away, the linchpin in the family becomes the grandmother or the mother. ${ }^{48}$ From the first explicit criticisms of the Zhou patriarchal order in the Laozi, through the wealth of wicked fathers in Ming and Qing fiction, to the revolt against the tyrannical authority of ancestors and fathers in 1919, we see that every step toward a modern conception of the self corresponded to a step further away from the father.

48. For example, in the Cui family in Wang Shifu's (1206-1368) The Story of the Western Wing (Xixiangji 西廂記), the Wen family in the Xia Jingqu's (1705-1787) Humble Words of a Country Codger (Yesou puyan 《野瞍曝言》), the Geng family in Suiyuan Xiashi's Lin Lan Xiang 林蘭香, the Tong family in Pu Songling's (1640-1715) Marriage as Retribution: A Story to Awaken the World (Xingshi yinyuan zhuan 《醒世姻緣傳》), the Jia family in The Dream of the Red Chamber, the Tan family in Li Luÿuan's (17071790) Lantern at the Crossroads (Qiludeng 歧路燈). Whether the father and master is absent or deceased, the household is controlled by the matriarch. 


\section{BibLIOGRAPHY}

ANONYMOUS ${ }^{1}$ (repr. 1986). Xingshi yinyuan 醒世姻緣. Taibei: Lianjing chuban shiye gongsi. AnONYmous (1815, repr. 1990). Tingyuelou 聽月樓. Shanghai: Shanghai guji chubanshe. Belliotti Raymond A. (1986). Honor Thy Father and Thy Mother and to Thine Own Self Be True. Southern Journal of Philosophy, $\mathrm{n}^{\circ} 24$ (2).

Belliotti, Raymond A. (1988). Parents and Children: A Reply to Narveson. Southern Journal of Philosophy, ${ }^{\circ} 26$ (2).

BenvéNISTE Émile (1969). Le Vocabulaire des institutions indo-européennes. Paris: Minuit. Birrell Ann (1982). New Songs of a Jade Terrace. An Anthology of Early Chinese Love Poetry. London/Boston: Allen \& Unwin.

Bo Xingjian 白行簡 (1991 repr.). Li Wa zhuan 李娃傳. Beijing: Zhonghua shuju.

CAO Xueqin 曹雪芹 (reed. 1964). Hongloumeng 紅樓夢. Beijing: Renmin chubanshe.

CoHen Paul A. (2009). Speaking to History: The Story of King Goujian in Twentiethcentury China. Berkeley: University of California Press.

Cur Xiangshan 崔象川 (ca 1836, repr. 1990). Bai Gui Zhi 白圭志. Shanghai: Shanghai guji.

English Jane (1979). What Do Grown Children Owe Their Parents?. In O’NeILl and RudDick (eds), Having Children. New York: Oxford University Press.

FENG Menglong (repr. 2003). Xingshi hengyan 醒世恆言. Changsha: Yuelu shushe.

FReUd Sigmund (1st ed., 1939, repr. 1955). Moses and Monotheism. New York: Vintage Books.

FueHrer Bernhard (1997). The Court Scribe's Eikon Psyches. A Note on Sima Qian and his Letter to Ren An. Asian and African Studies, ${ }^{\circ} 6$ (2).

Goldin Paul Rakita (2005). Sima Qian, "Letter to Ren An". In Victor H. MaIr, Nancy S. Steinhardt; Paul R. Goldin (eds), Hawaii Reader in Traditional Chinese Culture. Honolulu: University of Hawaii Press.

Guo Jujing 郭居敬 (repr. 1955). Ershisi xiao shixuan二十四孝詩選. Ann Arbor: Michigan University Library.

JIN Yong 金庸 (1985). Shediao yingxiong zhuan 射鵰英雄傳. Xianggang: Minghe she. Knapp Keith Nathaniel (2005). Selfless Offspring: Filial Children and Social Order in Medieval China. Honolulu: University of Hawaii Press.

Knechtges David (2008). 'Key Words,' Authorial Intent, and Interpretation: Sima Qian's Letter to Ren An. Chinese Literature: Essays, Articles, Reviews, n 30.

LAUWAERT Françoise (1999). Le Meurtre en famille. Parricide et infanticide en Chine, XVIII ${ }^{e}$-XIX ${ }^{e}$ siècle. Paris: Odile Jacob.

Levi Jean (1995). La Chine romanesque. Fictions d'Orient et d'Occident. Paris: Seuil. Levi Jean (transl.) (2008). Ho-Kouan-Tseu. Précis de domination. Paris: Allia.

1. The unidentified author reveals only the penname of Xi Zhou sheng 西周生, “the scholar of the Western Zhou". The identity of the author has spawned many scholarly discussions over the last decades without but the problem remains as yet unsolved. 


\section{Romain Graziani}

Li Chenyang (1997). Shifting Perspectives, Filial Morality Revisited. Philosophy East and West, $\mathrm{n}^{\circ} 47$ (2).

Li Luÿuan 李綠園 (repr. 1990). Qiludeng 歧路燈. Shanghai: Shanghai guji chubanshe.

Lu Qinli 逯欽立 (1983). Xian Qin Han Wei Nanbeichao shi 先秦漢魏晉南北朝詩. Beijing: Zhonghua shuju.

Lu Xun 魯迅 (1981 repr.). Lu Xun quanji 魯迅全集. Beijing: Renmin chubanshe.

O’NeILl Onora \& Ruddick William (eds) (1979). Having Children. New York: Oxford University Press.

Pusey James Reeve (1983). China and Charles Darwin. (Cambridge, Mass.): Council on East Asian Studies, Harvard University.

SchaAb-Hanke Dorothee (2012). 'Awaiting the Wise of a Future Generation': On the Rhetoric of Treason in the Shiji. «Rhetoric and Politics in Early China» (Paul van Els, Romain Graziani, Yuri Pines \& Elisa Sabattini, eds.), Extrême-Orient Extrême-Occident, $\mathrm{n}^{\circ} 34$.

SHI Nai'an 施耐庵 (1975). Shuihu 水潡. Beijing: Renmin wenxue chubanshe.

Song Geng (2004). The Fragile Scholar. Power and Masculinity in Chinese Culture. Hong Kong: Hong Kong University Press.

SurYUAN Xiashi 隨緣下士2 ${ }^{2}(1838$, repr. 1985). Lin Lan Xiang 林蘭香. Taipei: Tianyi chubanshe.

Xu Ling 徐陵 (ed.) (repr. 1985). Yutai xinyong 玉臺新詠箋注. Beijing: Zhonghua shuju.

TianRAN-Chisou 天然痴叟 (repr. 1994). Shi dian tou 石點頭. Nanjing: Jiangsu guji chubanshe.

WANG Xianshen 王先慎 (ed.) (repr. 1998). Han Feizi jijie 韓非子集解. Beijing: Zhonghua shuju.

WEN Kang 文康 (1878, repr. 1995). Ernü yingxiong zhuan 兒女英雄傳.Shanghai: Shanghai guji chubanshe.

Wu Cheng'en 吳承恩 (reed. 2003). Xiyouji 西遊記. Beijing: Waiwen chubanshe.

Wu Jingzi 吳敬梓 (1750, repr. 1999). Rulin waishi 儒林外史册. Changsha: Hunan renmin chubanshe.

Wu Yu 吳虞 (1917). Jiazu zhidu wei zhuanzhizhuyi zhi genjun lun 家族制度為專制主 意之根據論. Xin Qingnian 新青年, $\mathrm{n}^{\circ} 6$.

Wu Yu 吳虞 (Nov. 1919). Chiren yu lijiao 吃人與禮教, Xin Qingnian 新青年 $n^{\circ} 1$ ).

Wu Yu 吳虞 (repr. 1990). Shuo xiao 說孝. In Wu Yu wenlu 吳虞文錄. Shanghai: Shanghai shudian.

XIA Jingqu 夏敬渠 (1881, repr. 1990). Yesou puyan_野瞍曝言. Shanghai: Shanghai guji chubanshe.

Tang chuanqi 唐傳奇 (repr. 2005). Beijing: Zhongguo Chang'an chubanshe.

YANG Shuhui \& YANG Yunqin (transl.) (2009). Constant Words to Awaken the World. A Ming Dynasty Collection, vol. III. Seattle: University of Washington Press.

ZHENG Tingyu 郑廷玉 (repr. 1995-1999). Kanqian nu mai yuanjia zhaizhu zaju 看錢奴 買冤家債主雜劇. Shanghai: Shanghai guji chubanshe.

2. This is of course a pseudonym, meaning something like the Fate-Following Fool. The author remains unknown. 
Introduction: Founding Fathers, Foundering Fathers

\section{GLOSSARY}

An Xuehai 安學海

Baiguizhi 白圭志

baihua 白話

Baiyueting 拜月亭

Cui Xiangshan 崔象川

Dou E yuan 竇娥冤

Dou Tianzhang 竇天章

Duanyun 端雲

Du Bao 杜寶

Ernü yingxiong zhuan 兒女英雄傳

ershisi xiao二十四孝

$\mathrm{Fu}$ zi zhi jian mei you en 夫子之間沒有恩

Guan Hanqing 關漢卿

Guo Ju 郭巨

huaben 話本

Guo Ju 郭巨

Guo Jujing 郭居敬

Guo Xiaozi 郭孝子

Hongloumeng 紅樓夢

$\mathrm{Hu}$ Shi 胡適

Jia 家

Jia Baoyu 賈寶玉

Jia Jing 賈敬

Jia Ren 賈仁

Jia Zhen賈珍

Jia Zheng 賈政

Jin 金

Jin Ping Mei 金瓶梅

ji Yun 紀昀

junzi 君子

Kachô jia zhang 家長

Kan qian $n u$ 看錢奴

Ke Taipu 柯太仆

Liaozhai zhiyi 聊齊誌異

Li Gui 李桂

Liu Fan 六反

Minister Pei 裴尚書

Mudan Ting 牡丹亭

Naofanlou duo qing Zhou shengxian 鬧焚樓多情周勝仙

Ni Shuangfeng 倪霜峰

Pei Shaojun 裴少俊

Pei Xingjian 裴行儉 


\section{Romain Graziani}

$\mathrm{Pu}$ Songling 蒲松齡

Qiangtou ma shang 牆頭馬上

Ruilan 瑞蘭

Rulin waishi 儒林外史

Sekishi/ chizi 赤子

Shuihuzhuan 水滸傳

Shuo xiao 說孝

Sima Qian 司馬遷

Song Jiang 宋江

Tang Seng 唐僧

tianfu 田父

Tingyuelou 聽月樓

tongyangnü 童養媳

Wang benli tianya qiufu 王本立天涯求父

Wang Yuan 王原

Wang Yuanwai 王員外

Wenyan 文言

Women xianzai zenyang zuo fuqin 我们现在怎样做父亲

Wuchanghui 五猖會

Wu Jingzi 吳敬梓

$\mathrm{Wu} \mathrm{Yu}$ 吳虞

Xiaozi zhuan 孝子傳

Ximen Qing 西門慶

Xin Nianqing 新年青

Xingshi hengyan 醒世恆言

Xingyang gong 榮陽公

Xiyouji 西游记

Yang Shichang 楊時昌

yaonie 妖蕉

Yuanwai Wang 員外王

Yuan zaju 元雜劇

yufu 漁父

Zhang Tingxiu taosheng qiufu 張廷秀逃生救父

Zhongfu fu 眾父父

Zhou Changshou 周長壽

Zhou Dalang 周大郎

Zhou Rongzu 周榮祖

zong 宗

Zuo Si 左思 